\title{
THE STRATEGY OF SIMULATION OF POWERED LED LAMP SYSTEM (SOLAR CELL + DIESEL ENGINE) FOR TRADITIONAL FISHING VESSELS IN MAKASSAR
}

\author{
Iskandar S.C. ${ }^{1 *}$, Triyono M.B. ${ }^{2}$, Bambang SAP ${ }^{3}$, Idkhan A.M. ${ }^{1}$ \\ ${ }^{1}$ Department of Mechanical Engineering Education, State University of Makassar \\ ${ }^{2}$ Department of Mechanical Engineering Education, State University of Yogjakarta \\ ${ }^{3}$ Department of Mechanical Engineering Education, State Polytechnics of Malang \\ *E-mail: soet 54mks@yahoo.com
}

\begin{abstract}
This paper deals with explaining the importance of higher education research that is directed to the design the strategy of simulation of powered LED lamp system solar cell in future fishing vessels. The principal aim of this research is the utilization of renewable energy with the use of solar cell technology as a driver of lux system on fishing vessels. This research was a panel solar cell yields its power is 100 WP. It is applied to implement LED lamp with its power 100 WP. This wind energy is environmentally (clean energy), economically (cheapest), easy to operate and easy to maintain, also renewable energy. The method of analysis is quantitative approach using one way classification (analysis of variance or design of experiments). The finding of this research is accepted the null hypothesis or not differ significantly at $5 \%$ from each independent variable. The scenario and the parameters during the strategy simulation powered LED, solar cell as a power generated by The Fcount is higher than Ftable $(3635,27>5,77)$, so $\mathrm{HO}$ is rejected, it means at least there is one light intensity mean value that is produced by the different sun panel significantly on the real stage of $5 \%$. It is expected to encourage and motivate the fisherman public in developing and applying this technology, so that it can upgrade the fish production quality and increase the economic value of fishermen society.
\end{abstract}

\section{KEY WORDS}

Power LED; renewable energy, solar cell, economic value.

In Indonesia, industry Energy has an important role in the attainment of social, economic, and environmental goals for sustainable development, and is a supporter of national economic activities. The usage of energy in Indonesia is increasing rapidly in line with the economic growth and resident increase; to fulfill requirement of energy that is increasing, develop various kinds of alternative energies, including renewable energy (solar cell), which until now has not been widely exploited.

Solar cell is one of the energies currently being developed today by the Government of Indonesia because as tropical state, the solar energy potency is big enough. Based on irradiation, data of the sun mustered out of 18 locations in Indonesia, solar radiation in Indonesia can be classified as follows: for occidental area and Eastern Indonesia with distribution of irradiation in $\mathrm{KBI}$ around $4.5 \mathrm{kwh} / \mathrm{m}^{2} /$ day with monthly variation about $10 \%$; and in $\mathrm{KTI}$ around $5.1 \mathrm{kwh} / \mathrm{m}^{2} /$ day with a monthly variation of about $9 \%$.

Fishery potency of deconvolution in Indonesia spreads over all part of water territories of the Indonesia Sea such as in territorial sea waters, marine waters of the archipelago and marine waters Exclusive Economic Zone (ZEE). The width of water territory of Indonesia sea is estimated 5.8 million $\mathrm{km} 2$ with the longest coastline in world of $81,000 \mathrm{~km}$ and islands bunch of 17.508 , having fish potency estimated at 6.26 million tons/year which can be managed everlastingly with details of 4.4 million tons can be caught in water territory of Indonesia and 1.86 million obtainable tons from water territory ZEEI.

The problems of traditional fisherman, especially fieldsman, still use hold with ice block media as haul fish preservative media. Besides applying big cost, it also requires big storage space. While on the ship itself, it is very possible to install solar panels on the roof. So it enables scheme and making of hybrid power refrigerator. Energy yielded by solar cell hardly 
depends on weather and absorption time of energy which only happened in the day time. Therefore, it is necessary to conduct hybrid power research (solar cell + diesel engine) as energy for refrigerator on traditional fisherman ship (Ariawan, 2008).

\section{LITERATURE REVIEW}

The Sun Energy Electric Revival (SEER) is the revival that uses the sunshine as the electric producer source. The main tool is to catch, change and result the electric is Photovoltaic (PV) or it is generally called Module/Panel Solar Cell. By PV, sun shine is changed into the negative and positive electron flowing process in $\mathrm{PV}$ because of the electron difference. The result of these electron flowing is the direct current electric energy that can be used to fill the battery/accumulator according to the needed tension and ampere (Figure 1).

The set capacity total in the sun energy conversion nowadays is less than $0,008 \mathrm{GW}$ ( 8 $\mathrm{MW}$ ). The national sun energy reached $4,8 \mathrm{kWh} / \mathrm{m}^{2} /$ day (www.anekasurya.com). The advantage of SEER can be developed in the isolated region, especially in the unreachable region by the electric net/ state electric revival, hospitality environment, cheap operation cost and treatment.

The electric energy cost per kWh by using the earth heat energy is USD 0,08 (Rp. 800) and the electric selling price by PT PLN is USD 0,06 or around Rp. 650 per $\mathrm{kWh}$. The electric energy cost per kWh for electric revival using motor fuel is USD 0,12 (Rp. 1.200). The coal usage is cheap, but it produces the high pollution and emission.

Several SEER main components are as follows: Solar Panel; Solar Charge Controller; Battery; Inverter.

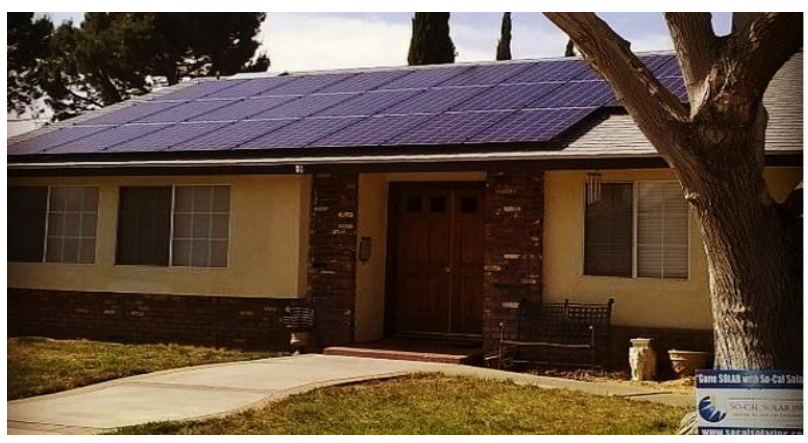

Figure 1 - Solar Cell energy (Source: http://www.energi-ku.com)
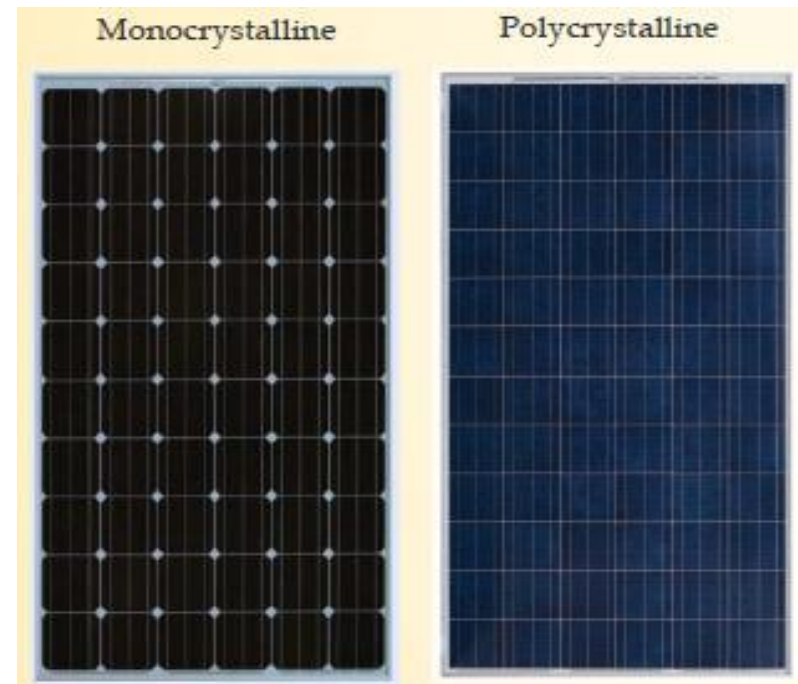

Figure 2 - The kind of Solar Cell Panel 
Table 1 - The Difference between Polycrystalline and Monocrystalline

\begin{tabular}{|l|l|l|l|}
\hline No. & Criteria & Polycrystalline & Monocrystalline \\
\hline 1 & Making Process & Simple & $\begin{array}{l}\text { Pure single silicone crystal made with the } \\
\text { process of czochralsky, complicated and } \\
\text { expensive process }\end{array}$ \\
\hline 2 & Price & Cheap & Expensive \\
\hline 3 & Heat Effect & $\begin{array}{l}\text { Low Temperature coefficient, } \\
\text { power reducing on every high } \\
\text { temperature increasing }\end{array}$ & $\begin{array}{l}\text { High Temperature coefficient, power } \\
\text { reducing on every high temperature } \\
\text { increasing }\end{array}$ \\
\hline 4 & Efficiency & Low & High \\
\hline 5 & Dimension/measurement & Big & Small \\
\hline
\end{tabular}

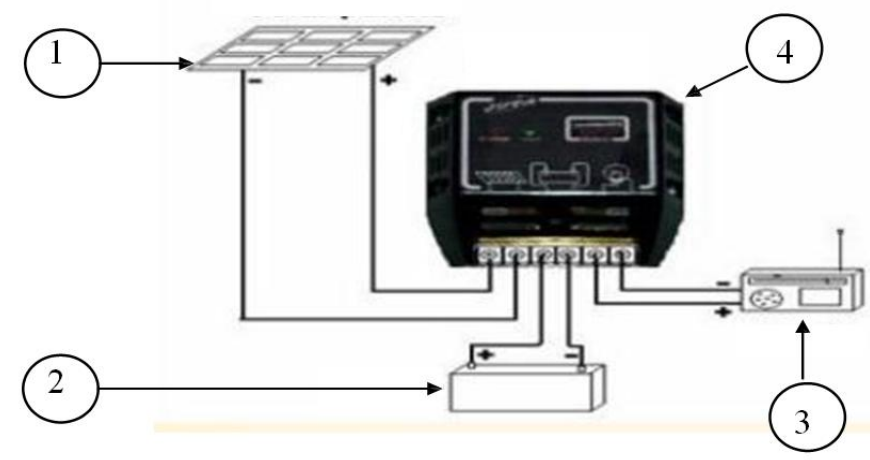

Figure 3 - Scheme of SEER (1 - Panel solar cell; 2 - Battery; 3 - Burden; 4 - Solar Charge Controller)

Solar Charge Controller (SCC) is the tool that functions changing DC solar panel tool into DC battery tension, and regulate the energy filling from solar panel to battery and regulate the energy usage from battery to the burden.

Battery is the tool to save the energy. The kind of battery nowadays is used for the need of SEER is AGM battery, Deep Cycle VRLA, GEL Battery, and Lithium. While the kind of battery based on the electric tension that often used on SEER is: battery with the tension $12 \mathrm{~V}$ and $24 \mathrm{~V}$. Inverter is the tool that functions to change from DC tension into AC tension.

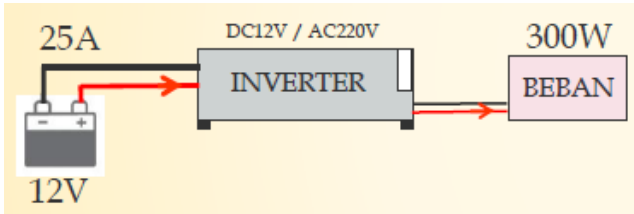

Figure 4 - Battery, inverter and burden

The power sum $(\mathrm{P})$ that produced can be counted with the formula are as follows:

$$
\mathrm{P}=\mathrm{V} * \mathrm{I}
$$

Where: $\mathrm{P}=$ is power [watt] or [W]; $\mathrm{V}=$ is tension [volt] or [V]; I = is current [ampere] or [A].

Project Based Learning (PBL) is the learning modern that have been developed in the progress countries as the United States. If it is translated into Indonesian, Project Based Learning means as the learning based project.

The learning based project (PBL) is the learning method that used the problem as the early step in collecting and integrating the new knowledge based its experience and real activity. PBL is designed to be used in the complex problem that needed learning in do investigation and understand it.

Simulation is an imitation process from something that is real and its state of affairs. The action of conducting this simulation describes the key characteristic qualities from the physical system behavior or certain abstract system (http://artikata.com). 


\section{RESULTS OF RESEARCH}

This research used the quantitative and qualitative approaches by referring the teaching method based on project (PBL). This research is conducted in the department of Mechanical Engineering in the State University of Makassar. The sun panel laboratory design with the power of 100 WP.

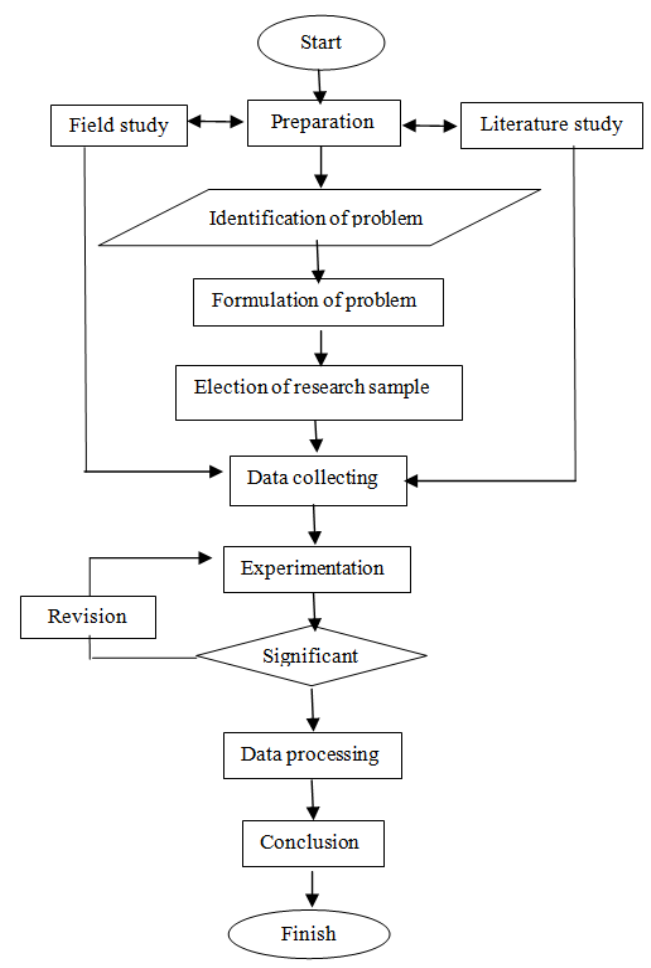

Figure 5 - Flow Diagram of Research activity

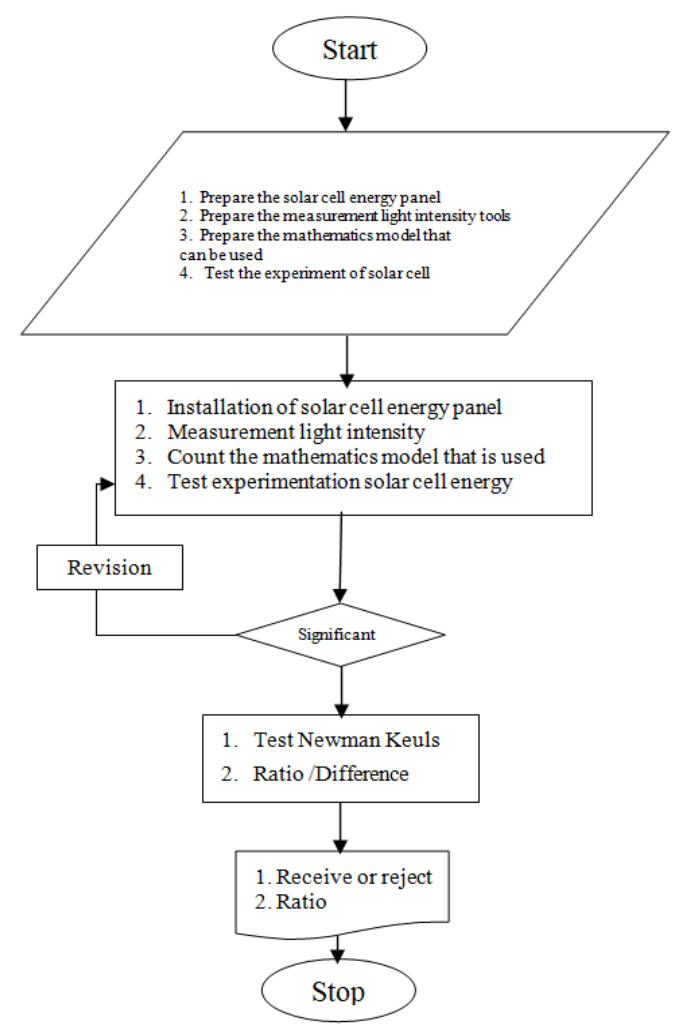

Figure 6 - Flow Diagram of Measurement light intensity 
The research subjects of the sun panel laboratory of $100 \mathrm{WP}$ are the students of Semester IV of Thermodynamics lecturer subject participants of Technique and Heat Transfer. The research instruments that used are as follows: Score of Thermodynamics with Conventional Method; Score of Thermodynamics lecturer subject with PBL method.

Data is taken from observation result by digital multi-tester measurement tool. Data collecting technique are by taken data is the primary data (from measurement result) and experimental test. Analysis is conducted by using experimental design of factorial experimental design (Miller, I, 1985: 389).

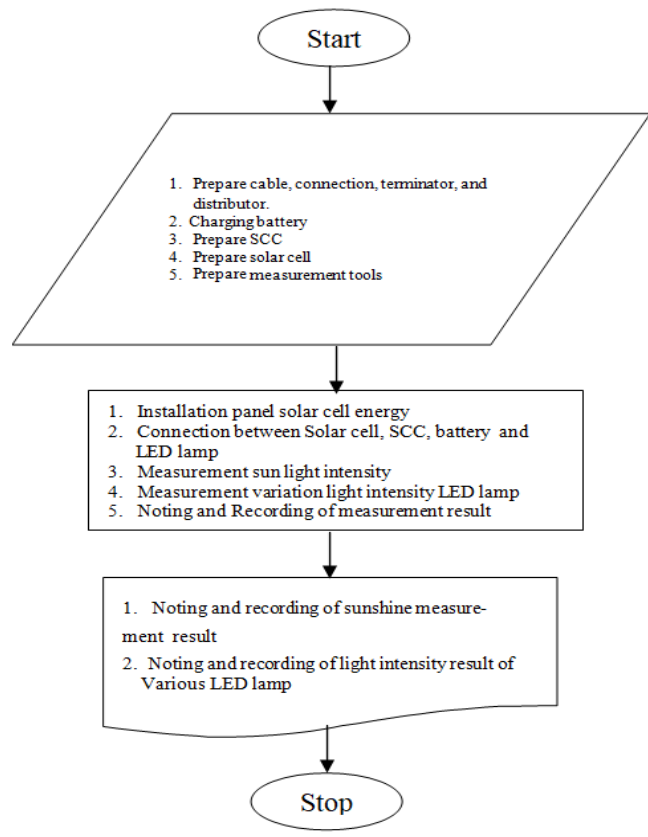

Figure 7 - Solar cell energy measurement

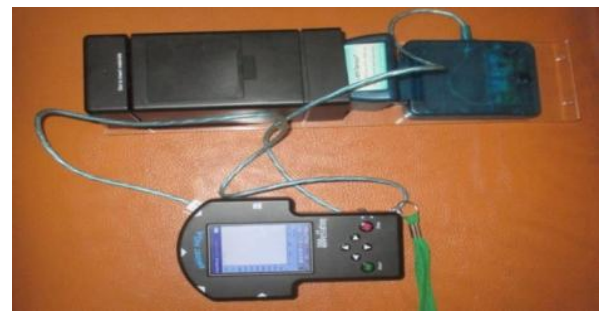

Figure 8 - Light sensor (for measuring light intensity)

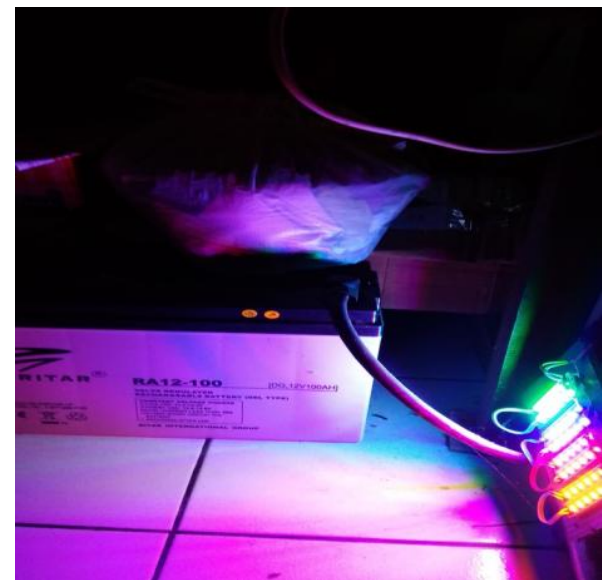

Figure 9 - LED lamp at several time "on"

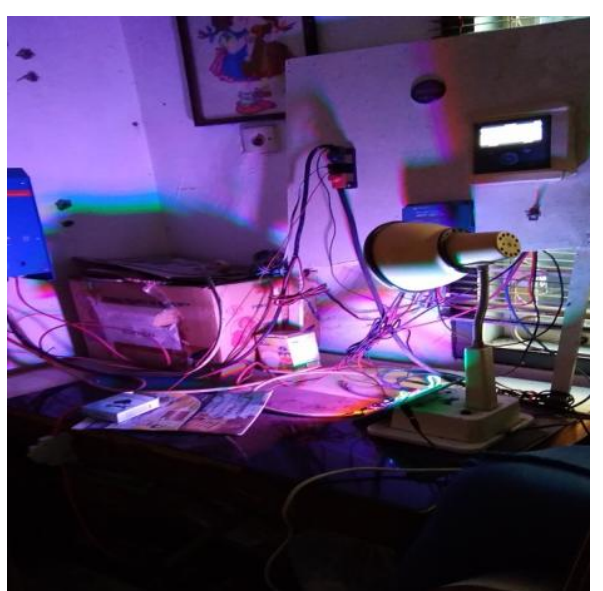

Figure 10 - Collecting data light intensity with used light sensor 


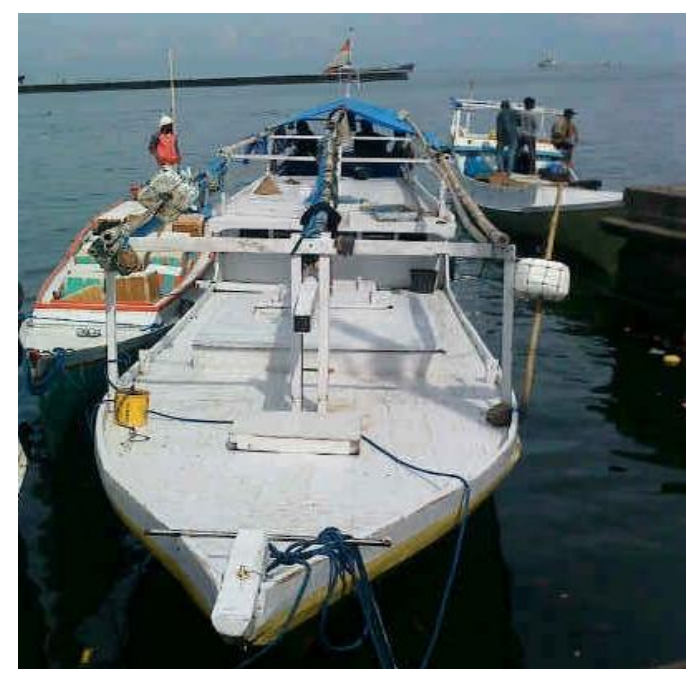

Figure 11 - Solar cell energy at fisherman vessel

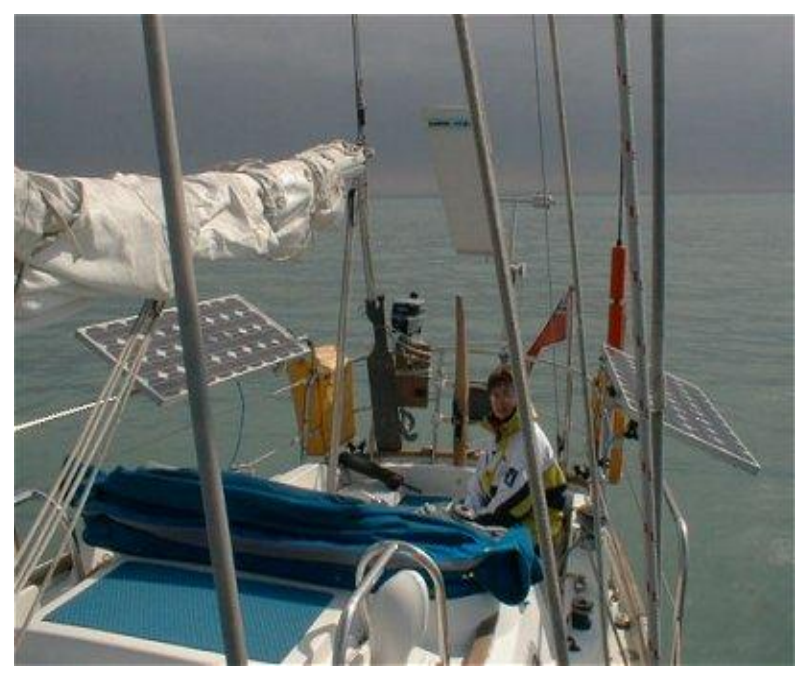

Figure 12 - Solar cell energy at fisherman vessel

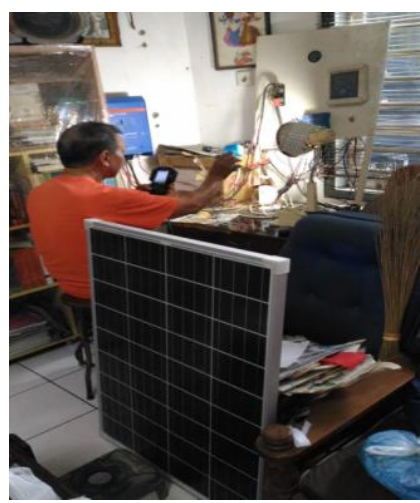

Figure 13 - Solar cell energy measurement at fisherman vessel

Table 2 - Time duration and light intensity (lux)

\begin{tabular}{|c|c|c|c|c|}
\hline \multirow{2}{*}{ Replication } & \multicolumn{4}{|c|}{ Light Intensity Measurement at Noon } \\
\cline { 2 - 5 } & 07.00 a.m & 12.00 a.m & 14.00 p.m & 238 \\
\hline 1 & 140 & 250 & 230 & 227 \\
\hline 2 & 138 & 221 & 228 & 223 \\
\hline 3 & 138 & 205 & 223 & 211 \\
\hline 4 & 130 & 194 & 213 & 209 \\
\hline 5 & 129 & 185 & 190 & 196 \\
\hline 6 & 122 & 182 & 179 & 151 \\
\hline 7 & 177 & 182 & 168 & 143 \\
\hline 8 & 162 & 180 & 133 & 134 \\
\hline 9 & 124 & 178 & 121 & 117 \\
\hline
\end{tabular}

Note: The primary data that had been managed.

Because $\mathrm{F}$ count $(5 \%, 3,37)$ is higher than Ftable $(5 \%, 3,37)$, so zero hypothesis is rejected, it means that the time difference against the light intensity mean is on the real stage of $5 \%$.

Table 3 - Analysis of Variance

\begin{tabular}{|l|l|l|l|l|l|}
\hline Source of variation & Df & SS & MS & Fratio & Ftable \\
\hline Treatments & 3 & $21,527.40$ & $7,175.80$ & 6.68 & 2.87 \\
\hline Error & 36 & $38,685.00$ & $1,074.58$ & & \\
\hline Total & 39 & $60,212.40$ & & & \\
\hline
\end{tabular}

Irwin Miller, 1985:332-341; Charles R Hicks, 1983:388. 


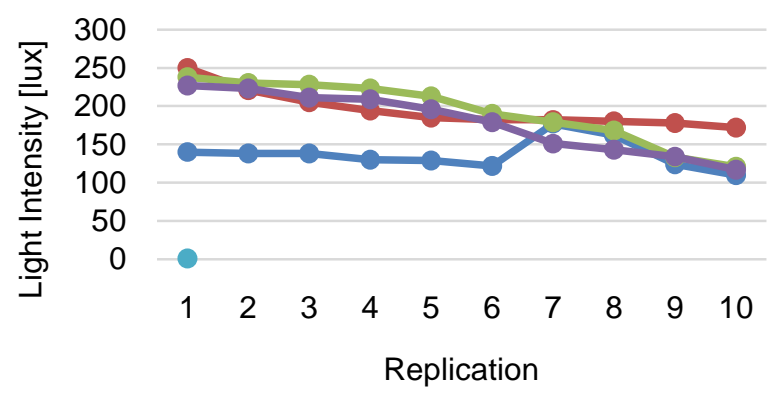

Figure 14 - Time vs Light Intensity (lux)]

It can be concluded that because Fcount is higher than Ftable $(6,68>2,87)$, so $\mathrm{HO}$ is rejected, it means that at least, there is one light intensity mean that had been produced by the significantly different sun panel on the real stage of $5 \%$. The counting is continued to analyze the difference by using Newman-Keuls range test (Charles R Hicks, 1983: 51).

Table 4 - One way Anova

\begin{tabular}{|c|c|c|c|c|c|}
\hline Source & Dk & Quadrat Sum & Middle Quadrat & Fcount & Ftable \\
\hline Inter treatment & 4 & 1399,276 & 349,81912 & 3635,9027 & 5,77 \\
\hline Galat & 24 & 2,405311 & 0,0962125 & - & - \\
\hline Total & 29 & 1401,682 & - & - & - \\
\hline
\end{tabular}

Because fcount is higher than Ftable $(3635,9027>5,77)$, so the zero hypothesis is rejected, it means at least - there is one significantly different wind velocity mean value against the electric power of KASV on the real stage of $5 \%$. The counting is continued to analyze the difference by using Newman-Keuls range test (Charles R Hicks, 1983: 51-54).

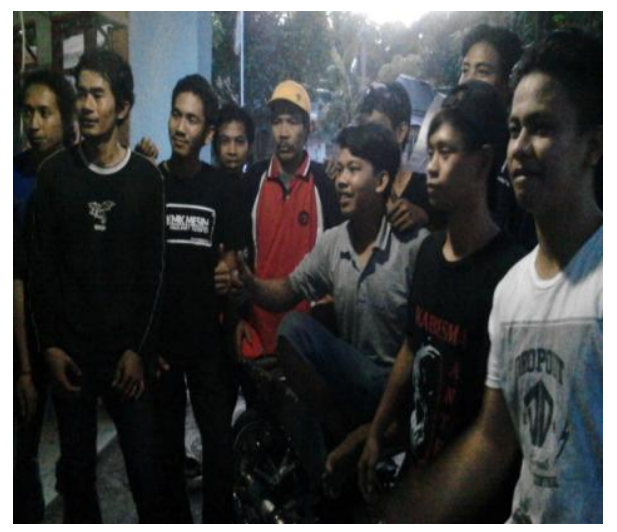

Figure 15 - Teaching Aids Making

PBL is comprehensive approach for teaching and learning that is designed so the learners do the research against the real problem. Where the educated participants in the complex problems, real world problems, wherever the educated participants can choose and decide the meaningful problem.

The educated participants are given chance to practice various skills that are needed for their adult life and career (how to allocate time, how to be responsible individual, private skill and learn through experience or experimentation).

\section{CONCLUSION}

Because $\mathrm{F}$ count is higher than Ftable $(3635,9027>5,77)$, so $\mathrm{HO}$ is rejected, it means there is one significantly sun panel light intensity on the real stage of $5 \%$. The highest sun panel light intensity value of LED are (23,467 and 7,35 lux). 
The stage that is done for PBL are socialization, practice of teaching aids making, teaching aids trial, participate in the competition and practice of PBL in the classroom and finally get gift as the first winner on the energy field on the Innovation and Technology competition (INOTEK) of 2017 that is hold by Malang city government and is participated on the national exhibition.

The $\mathrm{F}$ ratio is higher than Ftable. It means the zero hypothesis is accepted or is not different significantly at $5 \%$ from each independent variable. $(3635,9027>5,77)$, so zero hypothesis is rejected, it means at least - there is one significantly different wind velocity mean value against the electric power mean of KASV on the real stage of $5 \%$.

\section{SUGGESTIONS}

- The additional effort of watt peak on the sun panel that is expected in order to increase the light intensity and operation time;

- The additional effort of the additional tool on the sun panel that is expected can increase the light intensity;

- The way and practicing of PBL need to be socialized in front of the student.

\section{ACKNOWLEDGMENTS}

The authors wish to express their gratitude to the Ministry of Re- search, Technology and Higher-Education - Republic of Indonesia and The Director of State University of Makassar for their support.

\section{REFERENCES}

1. Arikunto, S. 2005. Research Management. Edition Revision. Penerbit Rineksa Cipta.

2. Ariawan, Pratama Risqi. 2008. Studi Awal System Hybrid between Diesel Engine With Solar Cell at Fisherman Vessel.

3. Hicks, C R. 1982. Fundamental Concepts in the Design of Experiments, Holt, Rinehart and Winston, New York.

4. IEA. 2008. Key World Energy Statistics, http://www.iea.org/statistics, 02 Desember 2008.

5. Kemp, WH. 2009. The Renewable Energy Handbook. Aztext Press. Canada.

6. Lacouture, DC, and Kathy O Roper, 2009. Renewable Energy in US Federal Buildings.

7. Journal of Facilities 27 (5/6): 173-186.

8. Maysha, Ima, Bambang Trisno, Hasbullah. 2013. The Usage of Sun Energy using Sun Panel Design Based on Transistor 2N3055 and Thermoelectric Cooler. Jurnal Electrans, Vol.12, No.2, September 2013, 89-96

9. Purwandari, Endhah dan Toto Winata. 2013. Efficiency Calculation Analysis of A- Si:H Solar Cells for Determination of Optimum Filament Temperature in Material Deposition. Jurnal ILMU DASAR, Vol.14 No. 1, Januari 2013: 29-32.

10. Purwono, BSA. 2016. Heat Transfer. Polinema Press. Malang.

11. Viehweger, Christian, et al, 2013. System Design and Energy Management for Indoor Solar Energy Harvesting Under Consideration of Spectral Characteristics of Solar Cells. International Journal of Measurement Technologies and Instrumentation Engineering, 3(1), 1-15, January-March 2013

12. Yuliananda, Subekti, Dan Gede Sarya, Ra Retno Hastijanti. 2015. The Influence of Sun Intensity Changing Against Sun Panel Output Power. Jurnal Pengabdian Lppm Untag Surabaya. November 2015, Vol. 01, No. 02, Hal 193 - 202.

13. Pudjanarsa, Astu. 2006. Energy conversion Engine. Yogyakarta: Andi Offset.

14. Soetyono. 2014. Heat transfer. Yogyakarta: Deepublish.

15. Soetyono. 2017. Energy conversion. Yogyakarta: Deepublish. 